\title{
Condensing economizers for large scale steam boilers
}

\author{
Iliya Iliev $^{1}$, Angel Terziev ${ }^{2 *}$, and Hristo Beloev ${ }^{1}$ \\ ${ }^{1}$ University of Ruse, Department of Thermotechnics, Hydraulics and Ecology, 8 Studentska Str., \\ 7017 Ruse, Bulgaria \\ ${ }^{2}$ Department of Power Engineering and Power Machines, Technical University of Sofia, 8 Kliment \\ Ohridski blvd., 1000 Sofia, Bulgaria
}

\begin{abstract}
An energy analysis and assessment of the feasibility of the development and implementation of a condensing economizer (CE) for steam generator TGM-96A has been made. The condensing economizer is characterized with a very high heating capacity of 21 to $23.5 \mathrm{Gcal} / \mathrm{h}$ and will cool the fuel gases from $123^{\circ} \mathrm{C}$ down to $47^{\circ} \mathrm{C}$. The utilized heat will be used to heat three water loops: two loops with District Heating Network water (DHN) and one with raw water from the Dnieper River. The expected improvement in the efficiency of the steam generator is $10.55 \%$. Complete thermal calculations of the condensing economizer have been carried out along with a definition by flow and temperature of the heat carriers. Based on the calculations of the heat and mass transfer processes, the thermal capacity of the economizer under the conditions of partial condensation of water vapor from the flue gases was estimated. The analysis presents an objective assessment of the project's investments, as well as other financial indicators and environmental benefits that give the investor the opportunity to put the project into operation.
\end{abstract}

\section{Introduction}

The efficient use of fuels in large energy boilers is predominantly related to the utilization of wasted heat from the exhaust gases. One of the ways to increase the energy efficiency is to use state-of-the-art condensing economizers to utilize the heat from the exhaust gases of the steam generators $[1,2,3]$. Common practice shows that at this stage deeper heat utilization from boilers burning natural gases, methane, and propane butane is more promising $[2,3]$. The efficiency of the boilers burning natural gas is in the range of $82-94 \%$ [4], estimated by the lower heating value (LHV). At temperatures between $110-220^{\circ} \mathrm{C}$ for the exhaust gases, the heat losses are estimated at $6-12 \%[1,4]$. In recent years, the socalled condensing boilers, in which the gas is cooled at temperatures below the dew point $\left(58-60^{\circ} \mathrm{C}\right)$, have gained popularity $[1,2,9]$. In these boilers both the physical heat of the gases and the latent heat of condensation are utilized, which allows the fuel efficiency to be

* Corresponding author: aterziev@,tu-sofia.bg 
significantly increased by up to $15 \%$. For example, in [5] it is shown that when the gas is cooled down to $0^{\circ} \mathrm{C}$, the amount of heat during condensation is $11.9 \%$ relative to the LHV of the natural gas. However, due to the absence of a source with such a low temperature, the gases are cooled to $20-40^{\circ} \mathrm{C}$, which to some extent reduces the effect of using condensation heat.

A number of studies [6] have found that the condensation of water vapors from flue gases dramatically increases the cost of each cooled degree. The most important factor in this cost increase is the initial moisture in the flue gases; the higher the moisture content, the higher the cost. To increase the efficiency of the conventional boilers by $1 \%$, a reduction of gas temperature by $15-20^{\circ} \mathrm{C}$ is needed. The same share of efficiency with condensing boilers can be achieved with cooling the gases by $2-3^{\circ} \mathrm{C}$ only. The aforementioned studies $[2,6]$ prove that when the exhaust gas is cooled from $150^{\circ} \mathrm{C}$ to $40^{\circ} \mathrm{C}$ the fuel economy reaches $10-12 \%$. Moreover, the heat loss of the exhaust gases, related to the upper LHV, is $2-3 \%$, with efficiency reaching $96-97 \%$. If the heat balance of the steam generator is made by the lower combustion heat, the efficiency reaches 105$107 \%[1,2,3,10]$.

\section{Subject of this energy analysis}

CHP-5 is the largest thermal power station in Ukraine with an installed thermal capacity of $1874 \mathrm{Gcal} / \mathrm{h}$ and installed electric power of $700 \mathrm{MW}$. The plant has four units, two power units of $100 \mathrm{MW}$ and two of $250 \mathrm{MW}$. The plant has two vertical water-tube steam generators, model TGM-96A; two co-current vortex steam boilers, model TGMP-314A; three water heating water-tube boilers, model PTVM-180; and two hot water boilers, model KVGM-180. The main fuel for the steam generators is natural gas, and fuel oil, M100, is used as a standby fuel.

CHP-5 provides domestic hot water to the 850,000 inhabitants of Kyiv, as well as heat energy to 3 million square meters of industrial buildings.

The heat energy is supplied through 6 main pipelines with diameters from $900 \mathrm{~mm}$ to $1200 \mathrm{~mm}$.

For both thermal and electricity production $800,000 \mathrm{~m}^{3}$ of natural gas, with a calorific value of $34,330 \mathrm{~kJ} / \mathrm{Nm}^{3}$ is consumed annually.

The construction of CHP-5 started in 1960. The first and second power blocks were put into operation in 1971-72 with the third and fourth in 1974-1976.

The subject of this energy analysis are the two TGM-96A steam generators. The gross thermal efficiency of the steam generators, according to their load, is within $\eta=92 \%$ to $94 \%$ at exhaust gases temperatures of $123^{\circ} \mathrm{C}$ to $125^{\circ} \mathrm{C}$.

The project's goal is to assess the opportunity for condensing the flue gases below the dew point cooling temperature, using a Condensing Economizer (CE) thereby increasing the efficiency of the steam generators by $8 \%$ to $10 \%$ - and also reducing natural gas consumption and $\mathrm{CO}_{2}$ and $\mathrm{NO}_{x}$ emissions while saving significant quantities of heat in CHP-5's regeneration cycle and the heat distribution network.

\subsection{Analysis of the Parameters for Determining the Degree of Flue Gas Cooling}

Today, indirect surface-type heat exchangers, using water as their coolant, are the most common. Their critical advantage is the provision of optimal price, performance and technological solution.

The key factor, that influences the residual heat of the flue gases utilization in this type of regenerative heat exchanger is the quantity and temperature of the cooling fluid (usually 
water) [7]. The secondary factors affecting the performance and design characteristics include: type of heat exchanger; pitch and arrangement of the heat exchanger's tubes; velocities of the gases and the water; pressure drop in water and gas flow; composition of the exhaust gases (including excess air ratio and air humidity); and heat exchange surface area/type $[8,9,10]$.

\subsection{Boilers' Capacity and Quantity of Exhaust Gases}

Based on the data provided by KTE:

- Boiler \#1 operates about 2,648 hours per year at an average capacity of $206 \mathrm{Gcal} / \mathrm{h}$ (240 MW);

- Boiler \#2 operates about 5,204 hours at an average capacity of $230 \mathrm{Gcal} / \mathrm{h}$ (268 MW).

Both boilers do not operate simultaneously with the CE - it operates with either boiler and will be switched from boiler to boiler as appropriate.

During three of the winter months, the average capacity of one boiler is about 259 $\mathrm{Gcal} / \mathrm{h}$, which is when the conditions for condensing mode are the best. Therefore, when determining the amount of exhaust gases required for calculating the size of the CE it is assumed that the maximum boiler capacity is $260 \mathrm{Gcal} / \mathrm{h}(302 \mathrm{MW})$.

Taking into consideration the quantity and the composition of the fuel and the combustion products, and the excess air ratio (which must not exceed 1.4), the amount of exhaust gas is assumed to be $411,000 \mathrm{Nm}^{3} / \mathrm{h}$. The analysis uses this method of estimating exhaust gas volume instead of calculating the theoretical amount of gas at full boiler capacity.

\subsection{Exhaust Gas Temperature}

The temperature of the exhaust gases at different time periods and loads ranges is between $110^{\circ} \mathrm{C}$ and $130^{\circ} \mathrm{C}$. This analysis assumes an average exhaust gas temperature of $123^{\circ} \mathrm{C}$.

\subsection{Quantity and Temperature of Water Flows for Gas Cooling}

A CE has one to several water inlets and outlets, with water flow rates and temperatures sufficient to cool the exhaust gases below the dew point of the water vapor in the flue gases at the respective partial pressure.

At CHP-5 it is possible to use three types of water streams: district heating net (DHN) water; additional water to refill the district heating system; or fresh water from the Dnieper river for the CE's technological needs.

\subsection{District Heating Network (DHN) Water}

Using water from the DHN's return water is a significant advantage for the CE as there is sufficient water at a temperature close to the condensation temperature of the water vapor in the flue gases.

It is possible to build the $\mathrm{CE}$ with two or three independent water loops and outlets in the exhaust flue gases, using DHN water with a flow rate of $2000 \mathrm{~m}^{3} / \mathrm{h}$ to $3000 \mathrm{~m}^{3} / \mathrm{h}$. The circulation pump with a required flow rate and head will be used to transport the water. Another possibility is to use the head of the network connected pumps, installed before the boiler system, for running the water through the economizer. (The different strategies will be considered during the CE's design process.) 
The DHN return water temperature ranges between $52^{\circ} \mathrm{C}$ and $55^{\circ} \mathrm{C}$ in the summer months - June, July and August. During the winter season the water temperature is between $46^{\circ} \mathrm{C}$ and $50^{\circ} \mathrm{C}$. Experience shows that when water temperature rises from $53^{\circ} \mathrm{C}$ to $55^{\circ} \mathrm{C}$ the outlet gas temperature is usually higher than $56^{\circ} \mathrm{C}$ to $58^{\circ} \mathrm{C}$ (when sufficient cooling water flow rate is present). At this temperature, the $\mathrm{CE}$ partially condenses the exhaust gases. Therefore, during the 4 summer months, the inlet water does not ensure a stable condensing process in the CE. During the winter period, the network water in the CE can utilize a power of 10 to $15 \mathrm{Gcal} / \mathrm{h}$, and in summer 8 to $10 \mathrm{Gcal} / \mathrm{h}$. The distance between the proposed CE site and the heating network is about $250 \mathrm{~m}$.

\subsection{Water Added to Compensate the Water Losses from the District Heating System (Makeup Water)}

The CE could use the district heating system's makeup water. The chemically treated and purified makeup water, with a flow rate of $400 \div 500 \mathrm{~m}^{3} / \mathrm{h}$ and a temperature of about $30^{\circ} \mathrm{C}$, could be used by the $\mathrm{CE}$ for providing year-round condensation of water vapor in the exhaust gases at almost all loads of the heating networks and the boilers. If this water source is used, it is recommended that the makeup water is heated by $10^{\circ} \mathrm{C}$ before entering the deaerator and added back to the heating network.

Adding water with such properties is an advantage ensuring condensation at the $\mathrm{CE}$ and saving about $8 \mathrm{Gcal} / \mathrm{h}$ to $10 \mathrm{Gcal} / \mathrm{h}$ of thermal energy output.

Circulation would be provided by a pump with suitable head and flow rate. The distance from the CE's proposed site to the makeup water source is about $80 \mathrm{~m}$ to $100 \mathrm{~m}$.

\subsection{Fresh Water from the Dnieper River for Technological Needs of the Plant}

The Dnieper River's waters could also serve as the CE's cooling water. Water circulation is supported by a pump with suitable pressure and flow rates. It is very likely that the river water would need to be treated. The distance to the water source (i.e., the Dnieper River) is about $80-100 \mathrm{~m}$.

Table 1. Average annual data of water loops of condensing economizer

\begin{tabular}{|l|c|c|}
\hline \multicolumn{1}{|c|}{ Element } & Unit & Value \\
\hline Average flow of DHN water of nearest network, $\mathrm{G}_{\text {avDHN }}$ & $\mathrm{m}^{3} / \mathrm{h}$ & 17,614 \\
\hline $\begin{array}{l}\text { Minimum flow of DHW (not accident) of nearest network, } \\
\mathrm{G}_{\text {minDHN }}\end{array}$ & $\mathrm{m}^{3} / \mathrm{h}$ & 15,009 \\
\hline $\begin{array}{l}\text { Maximum flow of DHN water (more than along a day), } \\
\mathrm{G}_{\text {maxDHN }}\end{array}$ & $\mathrm{m}^{3} / \mathrm{h}$ & 29,000 \\
\hline Average temperature of return network, $\mathrm{t}_{\text {ret }}$ & ${ }^{\circ} \mathrm{C}$ & 50.0 \\
\hline Number of hours with temperature $>\mathrm{t}_{\text {ret }}$ & $\mathrm{h} / \mathrm{year}$ & 4,104 \\
\hline Distance from network to CE, $\mathrm{m}$ & $\mathrm{m}$ & $\approx 250$ \\
\hline Diameter of the network pipes at the point of connections, $\mathrm{d}$ & $\mathrm{m}$ & 0.9 \\
\hline Operation time of network, $\mathrm{h}_{\text {net }}$ & $\mathrm{h} / \mathrm{year}$ & 8,760 \\
\hline Pressure of return network, $\mathrm{P}_{\text {net }}$ FEEDWATER FOR DHN & $\mathrm{MPa}$ & 0.33 \\
\hline \multicolumn{2}{|c|}{$\mathrm{m}$} & 512 \\
\hline Average feedwater flow, $\mathrm{G}_{\mathrm{F}}$ & $\mathrm{m}^{3} / \mathrm{h}$ & $20 \div 30$ \\
\hline Feed water temperature before heating, $\mathrm{t}_{\mathrm{H}}$ & ${ }^{\circ} \mathrm{C}$ & $\approx 80$ \\
\hline Distance between water source and CE & $\mathrm{m}$ & $15 \div 25$ \\
\hline \multicolumn{2}{|c|}{$\mathrm{RAW}$ RIVER WATER } \\
\hline Temperature of raw water after condenser, $\mathrm{t}_{\mathrm{RW}}$ & ${ }^{\circ} \mathrm{C}$ & 665 \\
\hline Average raw water flow, $\mathrm{G}_{\mathrm{RW}}$ & $\mathrm{m}^{3} / \mathrm{h}$ & \\
\hline
\end{tabular}


Table 1 presents the average annual flow and temperature data for the different possible water sources.

\section{Condensation Conditions}

The easiest and most straightforward way to significantly reduce CHP-5's fuel use is deep flue gas cooling to and below, the dew point temperature of water vapor in the flue gases and further use the latent heat of condensation.

The maximum amount of heat utilized from the flue gases is represented by the amount of heat released under full condensation (at a temperature below the dew point $t=0^{\circ} \mathrm{C}$ and moisture content of $\mathrm{d}=0 \mathrm{~g} / \mathrm{kg}$ dry gas) related to the lower heat value (LHV) of the fuel. The utilized latent heat is $11.9 \%$ more, related to the LHV - depending on the amount of air in the flue gases and its moisture content, the partial pressure of the gas mixture, the temperature of the gases, the characteristics of the cooling surface, etc. - this percentage may vary. There is no precise theoretical relationship used for determining the percentage of heat recovery in industrial-scale condensation in pipe economizers due to the significant physical, construction/design and other factors that affect the process.

However, a number of studies have shown that the condensation of water vapor in flue gases significantly depends on the excess air ratio, which changes the condensation temperature [8]. High excess air ratios may compromise the economizer's performance by limiting condensation and collecting a reduced share of the latent heat. By increasing the excess air ratio $(\alpha)$, flue gas condensation is hindered, in turn requiring deeper cooling of the flue gases. Therefore, an excess air ratio of $\alpha<1.4$ before and after the economizer is recommended, to allow the process of water vapor condensation in the flue gases to start at a temperature higher than $53.5^{\circ} \mathrm{C}$ (Figure 1). Reducing and maintaining the excess air ratio $(\alpha)$ at the lowest possible level is important for operating the CE in an efficient manner.

In conclusion, there are three potential water sources with the needed quantities and at the required temperatures able to cool and condense the flue gases from the boilers. The CE's maximum output is expected to be in the range of 21 to $23.5 \mathrm{Gcal} / \mathrm{h}$ ( 24.5 to 27.3 MW), which represents an increase in efficiency from $9 \%$ to $10.5 \%$. Generally, it is possible to achieve an additional increase of about $1 \%$ to $2 \%$, but this requires complex engineering and equipment, which are not cost effective.

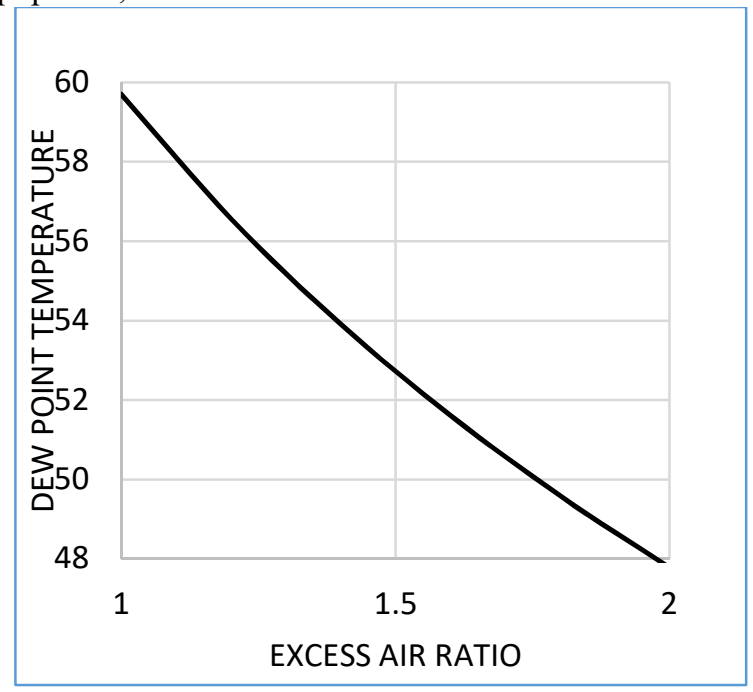

Fig. 1. Dependence between the dew point temperature and the excess air ratio [1] 
Fig. 2 shows the general appearance of the CE installed at Kyiv's CHP-6 after the ALSTOM water-heating boiler with a capacity of $180 \mathrm{Gcal} / \mathrm{h}$. The thermal capacity of the $\mathrm{CE}$ is $15.6 \mathrm{Gcal} / \mathrm{h}$, saving $8 \%$ to $10 \%$ of the hot water boiler's fuel consumption.

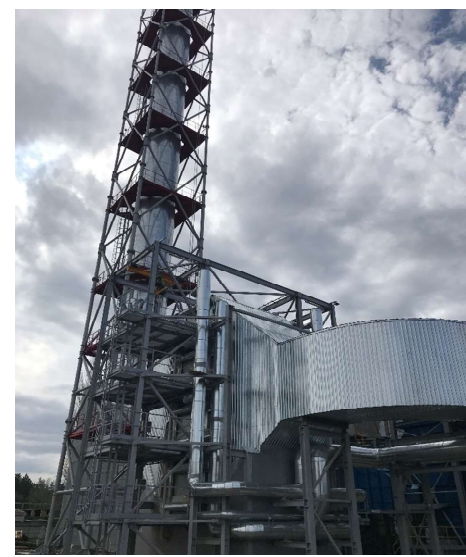

Fig. 2. The flue condensing economizer (CE) recently installed at CHP-6

This analysis assumes the following will take place at CHP-5: the CE will operate with an average real load on the boiler (see Table 2) of $222 \mathrm{Gcal} / \mathrm{h}$; the boilers will operate with an $8.6 \%$ increase in their efficiency (which is both theoretically, reasonably and practically possible), the CE's average annual power value is $21 \mathrm{Gcal} / \mathrm{h}$, and the $\mathrm{CE}$ has a stable and reliable operation and maintains its design parameters.

The average annual performance indicators of the CE, which can be switched between the two boilers, are presented in Table 2 .

A schematic of CHP-5's condensing economizer is shown in Figure 3. The figure shows the three water inlets and outlets and their temperatures as well as the temperatures of the incoming and outgoing flue gases used in the calculations.

Thermal calculations of the condensing economizer are performed with specialized software. Input data accepted for the analysis of the condensing economizer are presented in table 3.

The parameters that most strongly affect the degree of utilization of the residual heat of the flue gases in the concerned recuperative heat exchanger types are the flow rate and cooling fluid temperature.

The next other significant factors influencing the efficiency and design features are the type, step and pipes arrangement, optimal velocities of gases and water, acceptable resistance losses on the water and gas path, composition of the exhaust gases, incl. excess air coefficient, air humidity, and total heat exchange surface.

Input data analysis shows that when using the condensing economizers (CE) a couple of closed water loops with flow rates and temperature sufficient to cool the gases below flue gas dew point temperature at the respective partial pressure.

Three types of water flows are possible at CHP-5: network water supplied by the district heating network; additional water to fill the district heating system; raw water from the Dnieper River for the power plant's technological needs

The temperature of the returning network water is in the range from 52 to $55^{\circ} \mathrm{C}$ during the summer period (June, July and August). During the winter season the temperature is between $46-50{ }^{\circ} \mathrm{C}$.

The performed analysis and thermal calculations show that both in a winter and summer mode when the inlet water temperature in $\mathrm{CE}$ is in the range of $46-56^{\circ} \mathrm{C}$ and the optimal 
flow rate of the used network water is lower than $1000 \mathrm{~m}^{3} / \mathrm{h}$, the temperature of the exhaust gases will always be greater than the flue gas dew point temperature (which is $56-58^{\circ} \mathrm{C}$ ), i.e. this loop will operate as an ordinary economizer without condensation of water vapor from the flue gases. In this case the flue gases outlet temperature will also drop to about $75^{\circ} \mathrm{C}$.

In terms of the above, the partial condensation of water vapor in the flue gases will take place in the second or third contour of the CE. If main water runs in the second loop again at the same temperature and flow, condensation of water vapor in the flue gases will not occur again, but such a process will instead be initiated only on a part of the pipe wall surface.

Therefore a third loop with make-up water at a flow rate of $420 \mathrm{~m}^{3} / \mathrm{h}$ and temperature of $32^{\circ} \mathrm{C}$, is considered, while the gases will be cooled to about $45^{\circ} \mathrm{C}$, and condensation is expected to reach more than $60 \%$ (it is well known that practical results and empirical relations for degree of condensation are not available not only for different constructions but also for different condensation terms).

The results of reaching high levels of condensation can be achieved by using a third loop with filtered water for technological needs from the river at up to $620 \mathrm{~m}^{3} / \mathrm{h}$ and a temperature lower than $25^{\circ} \mathrm{C}$.

Table 2. Average annual data for one boiler incorporated with condensing economizer

\begin{tabular}{|c|c|c|}
\hline Element & Unit & Value \\
\hline Average steam boiler load, $\mathrm{G}_{\mathrm{st}}$ & $\mathrm{t} / \mathrm{h}$ & 372 \\
\hline Average natural gas consumption, $\mathrm{B}_{\mathrm{F}}$ & $\mathrm{Nm}^{3} / \mathrm{h}$ & 29,154 \\
\hline Average steam boiler output, $\mathrm{N}_{\mathrm{B}}$ & $\mathrm{Gcal} / \mathrm{h}$ & 222 \\
\hline Flue gas temperature after steam boiler, $\mathrm{t}_{\mathrm{FG}}$ & ${ }^{\circ} \mathrm{C}$ & 123 \\
\hline Excess air ratio in the burning chamber, $\alpha_{\mathrm{ch}}$ & - & 1.11 \\
\hline Excess air ratio after boiler, $\alpha_{\mathrm{AH}}$ & - & 1.4 \\
\hline Boiler efficiency (Gross) & $\%$ & 92.36 \\
\hline Total operating hours for both boilers & $\mathrm{h} /$ year & 7,800 \\
\hline
\end{tabular}

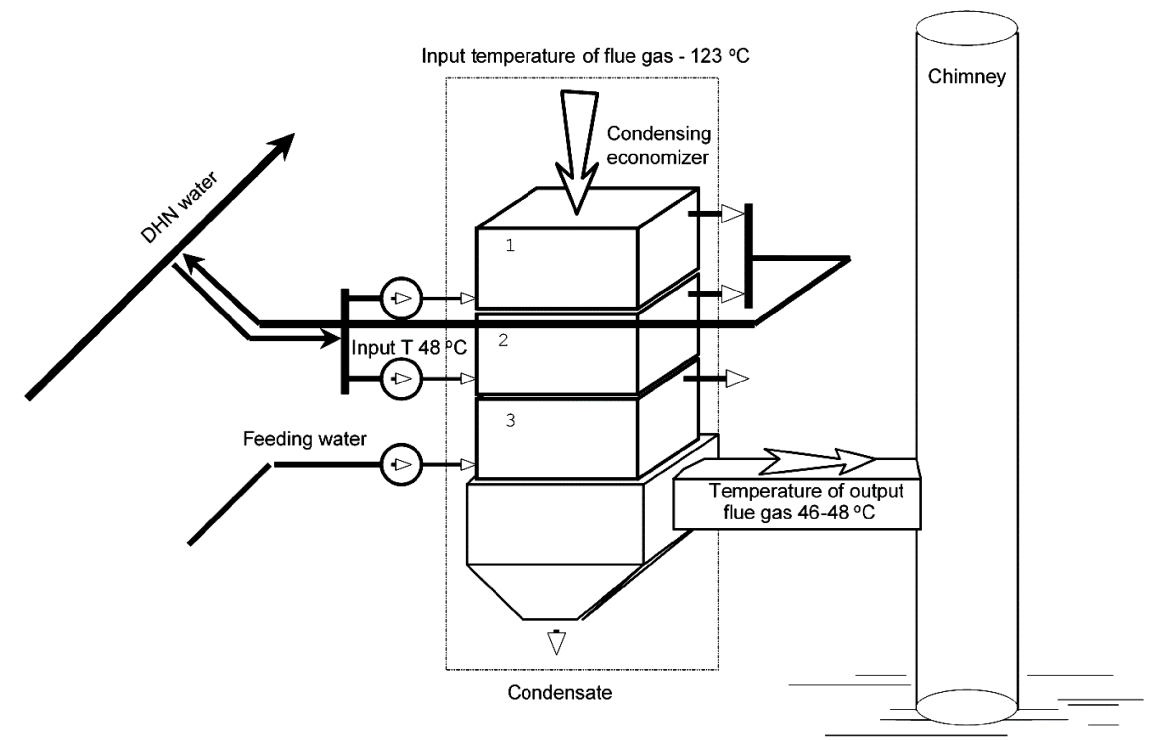

Fig. 3. The schematic of the condensing economizer proposed for implementation at CHP-5 
Table 3 presents the input data (composition and calorific value of the fuel, steam generator parameters, etc.) needed for the CE calculations.

Table 4 summarizes the calculation parameters used for the analysis of the CE.

Table 3. Input data for analysis of the condensing economizer

\begin{tabular}{|c|c|c|}
\hline Element & Unit & Value \\
\hline Low heating value (LHV), $\mathrm{Q}_{\mathrm{i}}^{\mathrm{r}}$ & $\mathrm{kJ} / \mathrm{Nm}^{3}$ & 34,330 \\
\hline Excess air ratio in the burning chamber, & - & 1.11 \\
\hline Maximum permissible value of the excess air after the air heater, $\alpha_{\mathrm{AH}}$ & - & 1.40 \\
\hline Nominal output of superheated steam, $\mathrm{D}_{\mathrm{sh}}$ & $\mathrm{t} / \mathrm{h}$ & 480 \\
\hline Flue gas temperature at the economizer inlet, $v_{\mathrm{FG}}$ & ${ }^{\circ} \mathrm{C}$ & 123 \\
\hline Flue gas enthalpy at economizer inlet, $\mathrm{H}_{\mathrm{FG}}$ & $\mathrm{kJ} / \mathrm{Nm}^{3}$ & $2,576.40$ \\
\hline Steam pressure in steam preheater, $\mathrm{P}_{\text {пе }}$ & $\mathrm{MPa}$ & 11.50 \\
\hline Steam temperature in steam preheater, $\mathrm{t}_{\mathrm{SP}}$ & ${ }^{\circ} \mathrm{C}$ & 540 \\
\hline Steam enthalpy in steam superheater, $\mathrm{h}_{\mathrm{sh}}$ & $\mathrm{kJ} / \mathrm{kg}$ & $3,460.40$ \\
\hline Feed water pressure, $\mathrm{P}_{\mathrm{FW}}$ & $\mathrm{MPa}$ & 14.60 \\
\hline Feed water temperature, $\mathrm{t}_{\mathrm{FW}}$ & ${ }^{\circ} \mathrm{C}$ & 230 \\
\hline Feed water enthalpy, $\mathrm{h}_{\mathrm{FW}}$ & $\mathrm{kJ} / \mathrm{kg}$ & 993.00 \\
\hline Enthalpy at saturation at $\mathrm{P}_{\mathrm{BSD}}$; h' & $\mathrm{kJ} / \mathrm{kg}$ & $2,788.65$ \\
\hline Pressure in the boiler drum, $\mathrm{P}_{\mathrm{BSD}}$ & $\mathrm{MPa}$ & 12.88 \\
\hline Heat loss from outgoing gases, $\mathrm{q}_{2}$ & $\%$ & 7.49 \\
\hline Heat loss from chemically incomplete combustion, $\mathrm{q}_{3}$ & $\%$ & 0.0 \\
\hline Heat loss from mechanically incomplete combustion, $\mathrm{q}_{4}$ & $\%$ & 0.0 \\
\hline Heat loss from radiation to the ambient, $\mathrm{q}_{5}$ & $\%$ & 0.13 \\
\hline Boiler efficiency & $\%$ & 92.36 \\
\hline
\end{tabular}

Table 4. Calculation parameters of the condensing economizer

\begin{tabular}{|c|c|c|}
\hline Element & Unit & Value \\
\hline \multicolumn{3}{|l|}{ Cooled flue gases } \\
\hline Flue gas temperature at the economizer inlet, $\mathrm{u}_{\mathrm{FG}}$ & ${ }^{\circ} \mathrm{C}$ & 123 \\
\hline Flue gas enthalpy at economizer inlet, $\mathrm{H}_{\mathrm{FG}}$ & $\mathrm{kJ} / \mathrm{Nm}^{3}$ & 2,576 \\
\hline Flue gas temperature at the economizer outlet, $\mathrm{u}_{\mathrm{EFG}}$ & ${ }^{\circ} \mathrm{C}$ & 47 \\
\hline Flue gas enthalpy at the economizer outlet, $\mathrm{H}_{\text {ЕКО }}$ & $\mathrm{kJ} / \mathrm{Nm}^{3}$ & 888 \\
\hline Maximum boiler capacity for calculating of $\mathrm{CE}, \mathrm{Q}_{\mathrm{cal}}$ & $\mathrm{Gcal} / \mathrm{h}$ & 260 \\
\hline Flue gas flow at average boiler capacity, $V_{G}$ & $\mathrm{Nm}^{3} / \mathrm{h}$ & 411,000 \\
\hline $\begin{array}{l}\text { Average boiler capacity delivering flue gases to } \mathrm{CE} \text { (at } \mathrm{Q}_{\mathrm{B}}=260 \\
\qquad \mathrm{Gcal} / \mathrm{h} \text { ), } \mathrm{Q}_{\text {aver }}\end{array}$ & $\mathrm{Gcal} / \mathrm{h}$ & 222 \\
\hline Average CE capacity (at average $Q_{B}=222 \mathrm{Gcal} / \mathrm{h}$ ), $\mathrm{Q}_{\text {aver }}$ & $\mathrm{Gcal} / \mathrm{h}$ & 21 \\
\hline
\end{tabular}




\begin{tabular}{|c|c|c|}
\hline Working hours & $\mathrm{h} /$ year & 7,800 \\
\hline Utilized waste heat (Heat energy savings) & Gcal/year & 163,323 \\
\hline Reduction of natural gas consumption (Natural gas savings), $\mathrm{B}^{\prime \prime} \mathrm{T}$ & $1000 \mathrm{Nm}^{3} / \mathrm{h}$ & 23,500 \\
\hline Heat loss from outgoing gases after construction of CE, q" 2 & $\%$ & -2.26 \\
\hline Boiler efficiency after construction of CE & $\%$ & 102.1 \\
\hline Boiler efficiency improvement & $\%$ & 10.55 \\
\hline \multicolumn{3}{|c|}{ Heated water in condensing economizer } \\
\hline Inlet network water temperature entering the economizer, t'DHN & ${ }^{\circ} \mathrm{C}$ & 50.0 \\
\hline Outlet network water temperature leaving the economizer, $\mathrm{t}$ "DHN & ${ }^{\circ} \mathrm{C}$ & 55.7 \\
\hline Network water flow, $\mathrm{G}_{\mathrm{NHW}}$ & $\mathrm{t} / \mathrm{sec}$ & 0.8 \\
\hline Feed water temperature entering the economizer, $t^{\prime}{ }_{\mathrm{HFW}}$ & ${ }^{\circ} \mathrm{C}$ & 28.0 \\
\hline Feed water temperature leaving the economizer, $\mathrm{t}$ "HFW & ${ }^{\circ} \mathrm{C}$ & 44.0 \\
\hline Feed water flow through economizer, $\mathrm{G}_{\mathrm{FW}}$ & $\mathrm{t} / \mathrm{sec}$ & 0.14 \\
\hline Inlet temperature of technological water from river Dnieper, $t^{\prime}{ }_{R W}$ & ${ }^{\circ} \mathrm{C}$ & 22.0 \\
\hline $\begin{array}{c}\text { Outlet temperature of technological water from river Dnieper, } \\
t{ }_{\mathrm{RW}}\end{array}$ & ${ }^{\circ} \mathrm{C}$ & 30.0 \\
\hline Technological water flow, $\mathrm{G}_{\mathrm{RW}}$ & $\mathrm{t} / \mathrm{sec}$ & 0.18 \\
\hline Circulating pump power $\mathrm{H}=22 \mathrm{~m} \mathrm{H}_{2} \mathrm{O}, \mathrm{m}=1700 \mathrm{~m}^{3} / \mathrm{h}-2$ circuits & $\mathrm{kW}$ & 700 \\
\hline Circulating pump power $\mathrm{H}=15 \mathrm{~m} \mathrm{H}_{2} \mathrm{O}, \mathrm{m}=600 \mathrm{~m}^{3} / \mathrm{h}-1$ circuit & $\mathrm{kW}$ & 150 \\
\hline Circulating pump power $\mathrm{H}=15 \mathrm{~m} \mathrm{H}_{2} \mathrm{O}, \mathrm{m}=900 \mathrm{~m}^{3} / \mathrm{h}-1$ circuit & $\mathrm{kW}$ & 240 \\
\hline Total electrical capacity of water pumps & $\mathrm{kW}$ & 1,090 \\
\hline Annual heat losses from network pipes to the CE & Gcal/year & 477 \\
\hline Decrease of specific nat. gas consumption after installing of CE & $\mathrm{Nm}^{3} / \mathrm{Gcal}$ & 118.8 \\
\hline
\end{tabular}

It is well known that carbon steel corrodes rapidly when exposed to hot condensing flue gases. When there is a presence of higher concentration of acidic components in the combustion gases, corrosion is accelerated.

Flue gas dew point corrosion occurs when these aggressive acids condense on carbon and stainless steels in the convection sections, flue ducts, and stacks [11]. The amount of contaminants in the fuel is directly correlated with the concentration of acid droplets, and therefore with the degree of corrosion itself. To mitigate these corrosive processes in the proposed $\mathrm{CE}$ more resistant materials in the construction of flues are installed.The flue gases will be discharged into the atmosphere via a chimney made of polymer composite materials with a high corrosion resistance and operational lifespan up to 50 years. This will avoid secondary condensation of water vapor in the chimney without applying the very common methodology of mixing condensed flue gases with hot gases before the chimney.

In order to avoid low temperature corrosion over the heating surfaces, ribbed pipes with extruded aluminum ribs are recommended for the $\mathrm{CE}$. The calculations are made on the basis of pipes $\mathrm{D}=32 \mathrm{~mm}$ and wall thickness of $2.3 \mathrm{~mm}$ with extruded aluminum ribs 320 $\mathrm{pcs} / \mathrm{m}$ and a rib height of $15 \mathrm{~mm}$. For the primary loop, where condensation of water vapor does not occur, carbon steel pipes can be used - boiler type st20 /GOST 9567-75; ГОСТ8733; DIN 2391; EN 10305-1/.

For the second and third loop surfaces where the process of water vapor condensation takes place and carbon and nitrogen oxides from the exhaust gases are dissolved in the condensate, the $\mathrm{pH}$ of the condensate is lower than 7. This suggests the use of alloy steel pipes with universal application type 304, 304L, 304H, which boast better corrosion resistance to nitric acid with concentrations below $65 \%$, as well as most other organic and inorganic acids.

It is mandatory that stainless-steel pipes resistant to carbonic acid and nitric acid in all are used in all water contours. It is recommended that the $\mathrm{CE}$ is designed as a vertical structure to permit a downward flow of the gases. Additionally, when the CE's condensate 
is to be used for technical needs or the district heating network considerations should be made to ensure that it is collected and neutralized (to a $\mathrm{pH}>7$ )..

\section{Project benefits}

The project's benefits are estimated based on calculations of the CE's energy use and efficiency:

\subsection{Heat energy \& natural gas savings}

After installing the CE, CHP-5 would use the waste heat of the boiler's exhaust gases. The boiler's exhaust gas temperature will be reduced from $123^{\circ} \mathrm{C}$ to $47^{\circ} \mathrm{C}$. DHN water (or heated feeding or raw water) will be running and heating in the CE's heat pipe bundles. Assuming an average boiler power of $222 \mathrm{Gcal} / \mathrm{h}$, an average power of the CE about 21 $\mathrm{Gcal} / \mathrm{h}$ and 7,800 operational hours per year, the CE will produce 163,800 Gcal/year. Considering the annual heat losses in the pipes to the CE of $477 \mathrm{Gcal} / \mathrm{year}$, the estimated heat savings are $163,323 \mathrm{Gcal} /$ year. $23,500,000 \mathrm{Nm}^{3} /$ year of natural gas would be needed to produce such an amount of thermal energy.

\subsection{Natural gas cost savings}

- Natural gas prices in Ukraine are regularly changing and the price change can be significant. Also, there are 2 different natural gas prices, depending on the type of energy (heat or electricity) produced by natural gas: "heat natural gas price" and "electrical natural gas price". KTE staff recommended that this SPFS use the "heat natural gas price", because the CE produces heat that otherwise (when the CE does not work) is produced by a hot-water boiler producing only heat. The data for "heat natural gas price" for 2018 , was provided by KTE, and is set in calculation model. This price is: $6,763.51 \mathrm{UAH} / 1000 \mathrm{Nm}^{3}\left(229.51 \mathrm{EUR} / 1000 \mathrm{Nm}^{3}\right)$.

- Extended forecasts for the changes in price of natural gas should be used in a more detailed feasibility study.

- For a natural gas price of $229.51 \mathrm{EUR} / 1000 \mathrm{Nm}^{3}$,the annual natural gas cost savings alone would amount to 5,393,454 EUR.

\subsection{Additional costs}

- The electricity price is 58.36 EUR/MWh based on KTE's average electricity production cost in 2018 (data provided by KTE).

- Electricity consumption of circulation pumps: Three water pumps with a total installed power of $1,090 \mathrm{~kW}$ are used for water circulation in the three loops of the CE with 7,800 operational hours per year. The pumps' annual electricity consumption is 8,502 MWh/year. At an electricity price of 58.36 EUR/MWh, the annual expenses are $496,159 \mathrm{EUR} /$ year.

- The costs for chemical reagents needed for neutralizing the condensate: with an average price of $20 \mathrm{EUR} / \mathrm{h}$ and with 7,800 operational hours, the annual costs are $156,000 \mathrm{EUR} /$ year.

- Net cost savings, calculated as a difference between the natural gas cost savings and additional costs, are estimated to be 4,741,295 EUR/year.

The CE project's net cost savings: EUR 4,741,295 per year. 
The preliminary capital investment costs estimated are EUR 9,739,167 including a contingency of EUR 205,833 or $2.11 \%$ taking into consideration the very preliminary status of the project.

This results in a 2.05 years estimated payback period, which is highly promising.

With the installation of the CE at CHP-5, annual $\mathrm{CO}_{2}$ emissions will drop by 44,791 $\mathrm{t} /$ year as a result of the $23,500,000 \mathrm{Nm}^{3}$ of natural gas saved each year. However, 8,502 $\mathrm{MWh} /$ year, of additional electricity will be used to power the water pumps, which will increase $\mathrm{CO}_{2}$ emission by $8,723 \mathrm{t}$ /year.

\section{Conclusion}

The energy analysis and assessment of the feasibility of the development and implementation of a condensing economizer (CE) for steam generator TGM-96A showed that:

- There is considerable potential for the recovery of waste heat from the boiler and boiler efficiency can be increased by $10.55 \%$ using a condensing economizer;

- The CE's maximum output is expected to be in the range of 21 to $23.5 \mathrm{Gcal} / \mathrm{h}(24.5$ to 27.3 MW);

- The energy saving measure would result in the following:

- Electricity consumption of circulation pumps will increase the overall CE electricity consumption: The pumps' annual electricity consumption is 8,502 $\mathrm{MWh} /$ year equal to an annual expense of 496,159 EUR/year.

- Thermal energy savings of $163,323 \mathrm{Gcal} /$ year;

- Natural gas consumption would be reduced by $23,500,000 \mathrm{~m}^{3} /$ year, amounting to cost savings of 5,393,454 EUR.

○ The proposed energy efficiency measure has a payback period of 2.05 years.

- Implementing the proposed condensing economizer will lead in particular to the reduction of the emissions of:

○ NOx by 52.17 tons/year;

- Carbon dioxide by 36,068 tons/year.

\section{References}

1. I. Z. Aronov, Contact heating of water by natural gas combustion products, St. Petersburg, (1990), (In Russian)

2. Iliev I. Means and methods for waste heat recovery from low-grade gas-steam flows. Monography, Publishing Centre at the Ruse university, (2013), (in Bulgarian)

3. Y.D. Georgiev, I.K. Iliev, G.D. Genchev, P.G. Mushakov, V.V. Bobilov. Investigation of heat and mass transfer in contact condensing economizer with "active" packing. Proceedings of University of Ruse, Vol 38, Series 5, (2001) (In Bulgarian)

4. Simplified Pre-Feasibility Study for Installing a Condensing Economizer at CHP-5 in Kyiv, Ukraine, Energy Security Project in Ukraine, (2019)

5. Consider Installing a Condensing Economizer, US Department of energy, Energy efficiency \& renewable energy, Steam Tip Sheet \#26A (2007).

6. U.S. Department of ENERGY, Energy Efficiency \& Renewable Energy DOE/GO102012-3393 (2012) https://www1.eere.energy.gov/manufacturing/tech_assistance /pdfs/steam26a_condensing.pdf

7. G.P. Negreanu, Numerical simulation of a large power steam turbine run-up, Int. J. Energy Technology and Policy, Vol. 6, Nos. 1/2, (2008) 
8. G.P. Negreanu, I. Pîşă, L. Mihaescu, I. Oprea, T. Prisecaru, V. Berbece, Experimental and numerical performance tests of the new $150 \mathrm{MW}$ unit of CHP Paroşeni, The Proceedings of CIEM 2009 (on CD), 4rd International Conference on Energy and EnviroNment, Bucharest, Romania, (2009)

9. C.I. Ioniţă, N. Vatachi, I.V. Ion, The Influence of the Dew Temperature of the Flue Gas on the Steam Boiler Performance, ECOS'98-Efficiency, Cost, Optimization, Simulation And EnviroNmental Aspects of Energy Systems And Processes, NancyFrance, 8-10 July, Vol. II, (1998)

10. K. Uzuneanu, I. Diaconescu - Analysis of New Technologies used for CHP Systems. Proceedings of $2^{\text {nd }}$ International Conference on Energy and EnviroNment Technologies and Equipment (EEETE'13), Brasov, Romania, (2013)

11. https://inspectioneering.com 